Fidei: Jurnal Teologi Sistematika dan Praktika, Vol. 3, No. 2, Des. 2020

Fidei: Jurnal Teologi Sistematika dan Praktika

Terakreditasi No: 85/M/KPT/2020 (Sinta 4)

e-ISSN: $2621-8135$

http://www.stt-tawangmangu.ac.id/e-journal/index.php/fidei

Vol. 3 No.2 (Des. 2020) hlm: 246-267

\title{
Peranan Hari Sabat Bagi Kehidupan Orang Percaya Masa Kini
}

\author{
Erlina Waruwu \\ Sekolah Tinggi Teologi Anugerah Misi Nias Barat, Indonesia \\ Email: erlin_wrw@yahoo.com
}

\begin{tabular}{|l|l|l|}
\hline Diterima: 30 Maret 2020 & Direvisi: 16 Oktober 2020 & Disetujui: 17 Desember 2020 \\
\hline
\end{tabular}

\begin{abstract}
Abstrak
Dalam perjalanan umat Kristen dari abad ke abad tema hari sabat menjadi kontroversial yakni muncul beragam pandangan bahkan cenderung saling bertolak belakang. Sebagian terdapat kelompok orang Kristen memiliki sikap mengabaikan hukum hari Sabat karena menganggap sama sekali tidak memiliki peranan penting bagi kehidupan orang percaya masa kini. Penelitian ini menggunakan metode induktif dan kajian kepustakaan. Alasan teologis menjalankan hari Sabat dan peranannya bagi kehidupan orang percaya. Pertama, berbicara dimensi vertikal agar umat Israel mengenang Allah untuk mengadakan persekutuan yang penuh sukacita dengan-Nya dan mengakui Allah sebagai Pencipta yang mengatur, memelihara, dan memiliki segala sesuatu, termasuk umat Israel. Selain itu, berhubungan dengan dimensi horisontal yang mengingatkan bangsa Israel bagaimana Allah telah melepaskan mereka dari penderitaan sebagai budak di masa lampau, sehingga mereka juga memberikan perhentian kepada seisi keluarganya. Kedua, sebagai perhentian yang diberikan-Nya adalah perhentian sebagai hasil dari kelepasan dari beban dosa dan perhentian eskatologis yang akan diterima semua orang percaya dalam dunia kekal di sorga. Ketiga, sebagai kesempatan untuk beribadah, melayani Allah dan sesama, serta bersekutu dengan sesama. Peranan hari Sabat bagi kehidupan orang percaya mencakup secara keseluruhan yakni secara rohani dan jasmani.
\end{abstract}

Kata-Kata Kunci: Hari Sabat; Peranan; Orang Percaya. 


\section{Abstract}

In the course of Christians over the centuries the theme of the Sabbath has become controversial, namely that various views have emerged and even tend to contradict one another. Some groups of Christians have an attitude of ignoring the Sabbath law because they consider it completely insignificant for the life of believers today. This research uses inductive methods and literature review. Theological reasons for observing the Sabbath and its role in the lives of believers. First, speaking of the vertical dimension so that the Israelites will remember God to have joyful fellowship with Him and acknowledge God as the Creator who governs, maintains, and owns everything, including the people of Israel. In addition, it relates to the horizontal dimension which reminded the Israelites how God had delivered them from the suffering of being slaves in the past, so that they also gave rest to their whole family. Second, the rest that He gives is the rest as a result of deliverance from the burden of sin and the eschatological rest that all believers will receive in the eternal world in heaven. Third, as an opportunity to worship, serve God and others, and fellowship with others. The role of the Sabbath for the life of the believer covers its entirety, namely spiritually and physically.

Keywords: Role; Sabbath; People Believe.

\section{Pendahuluan}

Dalam dunia kekristenan hari Sabat merupakan salah satu tema yang utama. Dikatakan utama, karena hari Sabat memiliki muatan teologis yang kental. Allah mengambil inisiatif untuk melakukannya terlebih dahulu sebelum menjadikannya suatu perintah yang termuat di dalam sepuluh hukum Allah yang dikenal dengan sebutan dekalog (Keluaran 20:4). ${ }^{1}$ Tercantumnya perintah keempat dalam dekalog merupakan hal yang penting dalam kehidupan bangsa Israel, yaitu kepercayaan mengenai providensi dan kemahakuasaan Allah yang dilatarbelakangi kehidupan bangsa Israel sebagai budak di Mesir yang harus bekerja tanpa henti. ${ }^{2}$ Dalam hal ini, hari Sabat memiliki peranan penting agar bangsa Israel bertumbuh pada pengenalan terhadap Allah yang telah membebaskan mereka dari perbudakan.

${ }^{1}$ David F Hinson, Sejarah Israel Pada Zaman Alkitab (Jakarta: Bpk. Gunung Mulia, 2001), 81.

${ }^{2}$ Yongky Karman, Bunga Rampai Teologi Perjanjian Lama (Jakarta: BPK. Gunung Mulia, 2005), 89. 
Dalam perjalanan umat Kristen dari abad ke abad tema ini menjadi kontroversial yakni muncul beragam pandangan bahkan cenderung saling bertolak belakang. Sebagian terdapat kelompok orang Kristen memiliki sikap mengabaikan hukum hari Sabat karena menganggap sama sekali tidak memiliki peranan penting bagi kehidupan orang percaya masa kini. Sebagian lagi terdapat sekelompok orang Kristen yang menerapkan tema ini berdasarkan pendekatan makna literal sehingga mengelompokkan orang-orang yang gagal menjalankan perintah tentang hari Sabat ke dalam kumpulan orang yang akan menerima hukuman kekal dalam api neraka. Selain itu, terdapat juga kelompok orang Kristen yang menerapkan perintah ini secara tersirat. ${ }^{3}$

Dengan beragamnya perbedaan pengertian dan penerapan tentang hari Sabat pada masa kini bermuara pada penafsiran makna dari tema hari Sabat di dalam Alkitab. Karena itu, dalam hal ini akan menyorot makna-makna teologis dari tema ini berdasarkan prinsip-prinsip biblika dengan pendekatan tematis dan kemudian menghubungkan peranannya bagi kehidupan orang percaya masa kini.

\section{Metode Penelitian}

Penelitian ini menggunakan metode induktif dan kajian kepustakaan. Peneliti berusaha mencari data atau fakta dalam nats-nats Alkitab yang berbicara tentang hari Sabat digunakan sebagai bahan bukti penafsiran. Peneliti juga menggunakan studi kepustakaan, yaitu dari literatur-literatur Kristen maupun sekuler yang berkaitan dengan penelitian untuk memperoleh makna teologis dan peranan hari Sabat bagi kehidupan orang percaya masa kini.

\section{Pembahasan dan Hasil}

Hari Sabat memiliki sejarah yang panjang, bermula dari penciptaan, dimana Allah berinisiatif untuk menguduskan hari ketujuh atau hari Sabat setelah selesai dari proses penciptaan-Nya. Berlanjut terus pada kehidupan bangsa Israel, dimana hari Sabat dimasukkan dalam dekalog, hingga pada gereja mula-mula sampai pada gereja masa kini. Di bawah ini adalah pembahasan mengenai sejarah hari Sabat.

${ }^{3}$ Timotius Fu, Perhentian Hari Sabat: Makna Dan Aplikasinya Bagi Orang Kristen, Veritas : Jurnal Teologi Dan Pelayanan, vol. 11 (Malang: Seminari Alkitab Asia Tenggara Malang, 2010), 231. 


\section{Hari Sabat Penciptaan}

Hari Sabat penciptaan dikenal karena adanya keterkaitan dengan proses penciptaan yang dilakukan Allah. Alkitab mencatat, dimana Allah berinisiatif untuk berhenti dari pekerjaan-Nya dalam mencipta pada hari ketujuh, Allah memberkati dan menguduskan hari ketujuh (Kej. 2:2-3). Inilah awal adanya hari Sabat.

Terkaitnya hari Sabat dengan peristiwa penciptaan bermakna bahwa hari Sabat adalah hari peringatan abadi akan penciptaan. Pemeliharaan hari Sabat merupakan suatu pengakuan bahwa Tuhanlah pencipta manusia dan alam semesta. ${ }^{4}$ Hal ini memiliki makna providensi Allah, ketika Allah selesai menciptakan tetap menopang ciptaan-Nya dengan pemeliharaan Allah.

Dalam hal ini, hari Sabat penciptaan pada mulanya adalah ide dan inisiatif Allah. Allah ingin manusia yang adalah ciptaan-Nya selalu mengingat penciptaNya yang menciptakan segala sesuatu dan itu harus dihargai, sebab apa yang diciptakan Allah baik adanya. Pemeliharaan hari Sabat yang nantinya menjadi suatu ketetapan, bertujuan agar manusia dapat meyakini akan providensi Allah yang terus ada sampai saat ini.

Lain halnya dengan Bruce A. Ray, berpendapat bahwa adanya hari Sabat penciptaan bukan hanya untuk kepentingan Allah semata-mata tetapi untuk kepentingan manusia yang telah diciptakan pada hari keenam. ${ }^{5}$ Dalam hal ini hari Sabat penciptaan merupakan peringatan pada karya Allah serta providensi Allah dengan tujuan untuk kepentingan Pencipta dan ciptaan-Nya. Yang dimaksud providensi Allah dalam hal ini yakni setelah selesai penciptaan pada hari keenam maka Allah mulai memelihara sampai hari ini.

\section{Hari Sabat Bangsa Israel}

Perkembangan hari Sabat selanjutnya adalah hari Sabat yang diperingati bangsa Israel yang bermula pada waktu mereka keluar dari Mesir. Dalam situasi yang menekan bagi mereka dimana tidak ada makanan, maka Allah memberi mereka makanan. Selama 6 hari mereka mendapat makanan berupa manna yang turun dari surga tetapi pada hari ketujuh manna tidak ada (Kel. 16:1-36).

Inilah awal penetapan Hari Sabat bagi bangsa Israel. Setelah itu dalam perjalanan bangsa Israel ke tanah perjanjian Allah kembali mengokohkannya

${ }^{4}$ Anton Silalahi, Hari Perhentian, Mengapa Hari Sabtu? (Jakarta: Talenta Mulia Aksara, 2008), 139-140.

${ }^{5}$ Bruce A. Ray, Merayakan Sabat (Surabaya: Momentum, 2006), 37-38. 
dengan memberikan kesepuluh hukum, yang pada hukum keempat adalah perintah mengingat dan menguduskan hari Sabat.

Hari Sabat yang termasuk dalam dekalog (Kel. 20:8-11) merupakan suatu hukum yang Allah tetapkan bagi bangsa Israel untuk menuntun pada kehidupan yang dikehendaki Allah. Makna Hari Sabat bagi bangsa Israel adalah mengingat bahwa Allah sebagai pencipta dan karya penyelamatan Allah bagi bangsa Israel dari tanah Mesir telah melepaskan dengan tindakan penebusan yang dasyat. Dengan demikian, hari Sabat menjadi bukti kovenan dan merupakan simbol dari hubungan khusus dalam anugerah antara Allah sebagai penebus dengan umat pilihan-Nya.

\section{Hari Sabat Gereja Mula-Mula}

Pada hari pertama dalam minggu setelah hari Sabat Yahudi, Yesus bangkit dan menyatakan diri kepada para Rasul dan murid-Nya. Ia mula-mula menampakkan diri kepada dua Maria (Mat.28:1) dan Malaikat Tuhan menyatakan bahwa Yesus telah bangkit (Luk.24:7). Pada hari itu juga Yesus menyatakan diri kepada dua orang murid dalam perjalanan mereka ke Emaus (Luk.24:13-35) dimana Ia menyatakan diri sebagai Messias (ayt.26), dan kemudian mereka menyaksikan hal itu kepada para murid lainnya yang sedang berkumpul bahwa "Sesungguhnya Tuhan telah bangkit" (ayat.34,46). Pada hari minggu itu untuk pertama kalinya setelah Ia menyatakan diri 'Bangkit' dan 'Tuhan', Ia berkumpul dengan murid-murid-Nya untuk makan roti perjamuan dengan mereka (ayat.30). Seminggu kemudian, pada hari minggu, Tuhan Yesus hadir dalam pertemuan para Rasul-Nya dimana Ia menunjukkan bekas paku di tubuhnya kepada Thomas. Thomas kemudian mengucapkan pengakuan yang jelas "Ya Tuhanku dan Allahku." (Yoh. 20:24-29). Pada hari minggu, 50 hari setelah kebangkitannya (Pentakosta), ketika para Rasul berkumpul, mereka dibaptiskan dengan Roh Kudus (Kis. 2) dan dilengkapi dengan kuasa (Kis. 1:8;2).

Hari Minggu telah memiliki identitas jelas sesudah kebangkitan Yesus yaitu sebagai: (1) Hari kenangan kebangkitan Yesus yang telah menang atas maut; (2) Hari itu menjadi hari penyataan yang jelas bahwa Yesus adalah 'Tuhan, (3) pertemuan mereka di hari minggu Pentakosta dibaptiskan dan dimeteraikan oleh Roh Kudus, dan dianggap sebagai kelahiran gereja Kristen. Pertemuan-pertemuan Tuhan Yesus dengan para Rasul di hari Minggu disusul kelahiran gereja juga di hari minggu Pentakosta, merupakan petunjuk jelas bahwa Tuhan hadir dalam persekutuan orang percaya di hari Minggu itu. Ini 
lebih diperkuat dengan kenyataan bahwa sejak kebangkitanNya, Alkitab tidak mencatat bahwa Tuhan Yesus mengunjungi ibadat Yahudi di hari Sabat! Karena itu bila selanjutnya para Rasul berkumpul untuk beribadat dan memecah roti di hari minggu, kelihatannya kebiasaan ini merupakan kenangan mingguan akan kebangkitan Yesus yang telah menyatakan diri sebagai Tuhan itu.

Selanjutnya, bagi para Rasul dan murid-murid Yesus yang berlatar belakang Yahudi, mereka masih menghadiri pertemuan Sabat Yahudi sebagai bagian dari tradisi ke Yahudian mereka, namun pengertian mereka mengenai hari Sabat itu sudah berbeda, bukannya mereka merayakan hari Sabat seperti pengertian orang Farisi dan ahli Taurat, tetapi seperti Rasul Paulus, ia masuk ke rumah ibadat Yahudi untuk mengajarkan firman Tuhan dan jalan Tuhan dan menobatkan orang Yahudi agar mengenal Yesus yang adalah Tuhan dan Mesias (Kis.13:13-48;14:1;18:4,19;19:8). Para Rasul sudah terbiasa menggeser tempat pertemuan ibadat mereka dari hari Sabat ke hari Minggu dan dari sinagoga ke rumah-rumah (Kis.20:7).

Rasul Paulus menyuruh mereka mengumpulkan uang persembahan pada waktu mereka berkumpul di rumah pada hari pertama tiap-tiap minggu (1Kor.16:2; saat itu mereka sudah terbiasa beribadat tiap-tiap hari minggu di rumah-rumah). Umat Kristen menyebut hari minggu sebagai 'hari Tuhan' (kuriake hemera, Why.1:10). Ini membuktikan hari Minggu pun memperoleh tempat yang istimewa bagi peribadatan Gereja mula-mula.

\section{Hari Minggu Dijadikan Hari Sabat Kristen}

Dalam perjalanan sejarah, kecenderungan untuk beribadah pada hari Minggu dengan cepat kian menguat sejak awal abad kedua "Hari Minggu" (Hari Tuhan) telah sepenuhnya mengambil tempat "hari Sabat" (Hari Sabtu). Berikut ini adalah penuturan langsung dari Eka Darmaputera:

Kitab penuntun ibadah resmi pada waktu itu, Didache (100 AD) menulis "Pada Hari Tuhan berkumpullah, pecahkan roti, dan selenggarakan ekaristi". Ignatius lebih gamblang lagi "Mereka yang telah meninggalkan kebiasaan lama, dan masuk ke dalam pengharapan baru, tidak boleh lagi hidup untuk hari Sabat, melainkan untuk hari Tuhan." Nada yang sama dijumpai dalam tulisan bapak-bapak gereja lainnya seperti Yustinus Martir, Dionysius dari Korintus, Tertulianus, Athanasius, sampai Agustinus. Sidang Sinode di Laodikia (363 AD), secara resmi memutuskan "Orang-orang Kristen tidak boleh mengyahudikan diri mereka dengan beristirahat pada hari Sabat. Pada hari itu mereka harus bekerja, dan baru pada hari Tuhan mereka harus beristirahat sebagai 
orang-orang Kristen.” Proses ini menjadi lengkap, ketika pada tahun 321, Kaisar Kontantinus Agung menetapkan dalam Undang-undang Negara "semua pekerjaan di kota harus berhenti pada hari Tuhan, kecuali bila karena terpaksa seperti pekerjaan bertani di desa supaya tanaman tidak rusak. $^{6}$

Para reformator secara konsisten mengikuti tradisi gereja purba tersebut, tetapi dengan tambahan nuansa yang menarik. Marthin Luther, dalam "Katekismus Besar", menekankan pentingnya para pekerja, pelayan dan hamba yang sehari-hari telah bekerja keras, memperoleh kesempatan untuk penyegaran dan beristirahat, dan terutama untuk mendengarkan firman Tuhan, memuji serta berdoa kepada-Nya. Tetapi secara prinsipal hari itu hari apa sebenarnya tidak penting. Semua hari sama baiknya dan sama kudusnya. ${ }^{7}$

Calvin pun demikian, untuk membuang ketahyulan yang melekat, hukum hari Sabat sebagai bagian dari Taurat dan "hari suci" orang Yahudi dinyatakan tidak berlaku bagi orang-orang Kristen. Namun orang-orang Kristen masih tetap memelihara jiwanya, yaitu perlunya hidup dengan sopan, tertib dan damai dalam hubungan dengan Allah, khususnya melalui ibadah dalam gereja. Untuk itu ditetapkan hari lain yakni hari Minggu sebagai pengganti. Hari Tuhan adalah hari sukacita. Sedangkan menurut Pengakuan Iman Webminster Perintah keempat tidak memerintahkan untuk mengingat hari ketujuh dalam arti urutan waktu, tetapi memerintahkan untuk menaati hari ketujuh menurut proporsi waktu. Karena perintah keempat membawa untuk menaati sepertujuh dari waktu sebagai Sabat, maka tidak ada bagian dari perintah keempat yang tidak bisa diterapkan sepenuhnya di hari pertama (atau hari-hari lainnya) merupakan sepertujuh bagian sejauh dilihat dari proporsi waktu. ${ }^{8}$

Sebagaimana Perjamuan Tuhan menggantikan Sakramen Paskah dalam Perjanjian Lama, kematian Kristus menggantikan persembahan kurban bakaran di atas mesbah, kedudukan Imam Besar Kristus menurut peraturan Melkisedek menggantikan keimaman Harun dan mengangkat setiap orang beriman yang telah dilahirkan baru menjadi Imam Allah, demikian pula dengan pemeliharaan hari Sabat ada perubahan simbol yang sesuai dengan peraturan yang baru. ${ }^{9}$ Yesus bangkit dari antara orang mati pada hari yang pertama Minggu itu, sesuai

${ }^{6}$ Eka Darma Putera, "Hak Beristirahat Untuk Yang Bekerja,” accessed March 12, 2020, https://archive.org/stream/ ekadarmaputera/.

${ }^{7}$ Martin Luther, Katekismus Besar (Jakarta: BPK. Gunung Mulia, 2007), 45.

${ }^{8}$ G I Williamson, Pengakuan Iman Westminster (Surabaya: Momentum, 2006), 263.

${ }^{9}$ Gleason L. Archer, Encyclopedia of Bible Difficulties (Malang: Gandum Mas, 1982), 194. 
catatan empat penulis Injil (Mat. 28:1; Mark. 16:2; Luk.24:1; Yoh.20:1). Jadi, hari Minggu dalam setiap Minggu mempunyai arti penting secara khusus untuk merayakan kemenangan yaitu hari kebangkitan. Eka Darmaputera memberikan pendapat bahwa tidak ada kebangkitan tidak ada kekristenan:

"Sebab dari sudut pandang iman kristiani, hari Minggu adalah hari dimana Tuhan bangkit dari kematian. Karena itu patut, layak, bahkan harus dirayakan! Betapa tidak? Kebangkitan Yesus dari kematian, adalah awal dari semua era yang sama sekali baru. Membuat arah sejarah dunia dan umat manusia jadi berbeda sekali secara principal dibandingkan era sebelumnya. 1Korintus 15:14 mengatakan "Andaikata Kristus tidak dibangkitkan maka sia-sialah peberitaan kami dan sia-sialah kepercayaan kamu." Jadi kesimpulannya, tidak ada kebangkitan maka tidak ada kekristenan."10

Jadi, sejarah hari Minggu dijadikan hari ibadah bagi umat Kristen, yang pertama hari Minggu merupakan hari dimana Yesus bangkit yang merupakan tanda kemenangan bagi iman orang percaya. Kedua memiliki tujuan yang positif bagi iman kristiani yakni memberikan pemahaman dan konsep yang benar dimana hukum Hari Sabat bukanlah berpatokan pada hari tertentu namun esensi dari hari itu sendiri, jadi tidak ada salahnya jika dijalankan pada hari Minggu. Hal ini pun mengantisipasi tidak terjadinya sinkritisme dan legalisme dalam kepercayaan kepada Kristus.

\section{Hari Sabat dalam Perjanjian Lama}

Dalam konteks Perjanjian Lama berdasarkan penelusuran teks-teks Alkitab yang membicarakan tema hari Sabat, dapat ditemukan sebuah pokok pikiran utama bahwa hari Sabat adalah hari perhentian. Kata "perhentian" merupakan perintah untuk menjalankan hari Sabat di Perjanjian Lama. Perintah ini muncul dengan jelas dalam teks pertama di dalam Alkitab yang memperkenalkan tema hari Sabat kepada bangsa Israel di Keluaran 16:21-30. Dalam Kel.20:8-11, memberikan suatu arti bahwa Allah sendiri yang menetapkan perintah untuk menguduskan hari Sabat. Penetapan hari Sabat harus diresponi dan diterapkan dalam kehidupan umat-Nya. Secara eksplisit menguduskan hari Sabat umat-Nya dapat mengingat akan karya penciptaan yang telah Allah lakukan melalui persekutuan dalam dimensi vertikal antara umat Israel dengan Allah serta adanya alasan kemanusiaan untuk memberikan waktu berhenti dari pekerjaan. Secara konkret, persekutuan ini

${ }^{10}$ Eka Darmaputera, Sepuluh Perintah Tuhan, Museumkan Saja? (Yogyakarta: Gloria Graffa, 2005), 87. 
dimanifestasikan dalam sebuah ibadah yang penuh sukacita karena bangsa Israel telah memasuki sebuah hari yang diberkati dan dikuduskan Allah. Pada saat yang sama, ibadah tersebut juga merefleksikan sebuah pengakuan bahwa Allah adalah Sang Pencipta yang memiliki dan memelihara alam semesta beserta segala isinya, termasuk bangsa Israel.

Selain itu, perintah Allah agar orang Israel memiliki perhentian pada hari Sabat terdapat pada Ulangan 5:15, yakni supaya mereka mengingat bahwa dulu mereka adalah budak di Mesir dan Allah telah melepaskan mereka keluar dari perbudakan tersebut dengan tangan yang kuat dan lengan yang teracung. ${ }^{11}$

Allah memberikan perintah mengenai hari Sabat merupakan hal yang serius, karena Allah pun menetapkan hukuman bagi yang melanggarnya. Dalam Keluaran 35:2 dikatakan bahwa orang yang melanggarnya pasti dihukum mati. Ini berarti bahwa perintah untuk menguduskan hari Sabat harus benar-benar dijalankan. Hal ini sesuai dengan U1.5:12 dimulai dengan kata "tetaplah ingat" menurut terjemahan LAI. Bahasa Ibrani "שישמוֹר" translitrasinya adalah "syamor" bentuk kata Qal infinitife absolute. Kata ini berfungsi untuk menguatkan (tetap, harus), yang memiliki arti "observing" 12 yakni mengamati, melihat, meninjau menjalankan, mematuhi, memperhatikan, menghormati. Jadi kata "tetaplah ingat" memberikan suatu tekanan adanya suatu keharusan untuk mengingat hari Sabat. Mengingat yang dimaksud bukan sekedar mengingat dan melupakan tetapi adanya suatu tindakan untuk menjalankan, menghormati hari Sabat.

Dengan demikian dapat disimpulkan bahwa menjalankan hari Sabat adalah mengadakan perhentian dari segala pekerjaan. Alasan perhentian ini adalah agar bangsa Israel di dalam sebuah persekutuan yang penuh sukacita mengakui Allah sebagai Pencipta yang memelihara dan memiliki mereka. Selain itu, perhentian juga merupakan kesempatan untuk menerapkan nilai-nilai kemanusiaan dengan melakukan kebaikan kepada sesama.

\section{Hari Sabat dalam Perjanjian Baru}

Dalam Perjanjian Baru praktek hari Sabat mengarah pada legalisme sehingga perayaan dan pemeliharaannya kehilangan manfaatnya. Peraturanperaturan yang dibuat oleh pemuka agama/ahli Taurat dan orang farisi

\footnotetext{
${ }^{11}$ Fu, Perhentian Hari Sabat: Makna Dan Aplikasinya Bagi Orang Kristen, 11:233.

${ }^{12}$ Judith M. Hadley and J. J. Owens, "Analytical Key to the Old Testament 4: IsaiahMalachi," in Vetus Testamentum, vol. 41 (Joshua: Grand Rapids, 1991), 778.
} 
menjadikan hari Sabat suatu beban bagi orang Yahudi. ${ }^{13}$ Peraturan-peraturan kasuistik $^{14}$ yang sangat rumit membuat hari Sabat kehilangan peranannya. Ada 39 kegiatan terlarang berdasarkan traktat Mishnah 7:2, antara lain menabur, membajak, menuai, mengikat berkas-berkas (gandum, dan lain-lain), mengirik, menampi, memilih, menggiling, mengayak, membuat adonan, membakar (roti, dan lain-lain), menggunting (bulu domba, dan lain-lain), mencuci pakaian, memukul (kain, dan sejenisnya), mengecat (kain, dan sejenisnya), memintal, menenun, membuat sosok kain dua rangkap, menenun dua lembar benang, memisahkan dua lembar benang, mengikat, melepaskan ikatan, menjahit dua potong kain, merobek, memasang perangkap, menyembelih hewan, menguliti hewan, menggaram daging, membalut kulit, mengikis kulit, menggunting kuku, menulis dua buah huruf, menghapus dua buah huruf, membangun (rumah), merobohkan (rumah), memadamkan api, menyalakan api, memukul dengan palu dan membawa barang dari rumah ke tempat umum. ${ }^{15}$

Kegiatan-kegiatan terlarang di atas ternyata baru permulaan dari hal-hal yang tidak boleh dilakukan pada hari Sabat, masih banyak lagi hal-hal yang tidak diperbolehkan pada hari Sabat seperti yang terdapat pada Misyna Syabbat $22: 6 ; 10: 6 ; 1: 3 ; 6: 8 ; 12: 3-5 ; 15: 2 ; 16: 1-4$. Di bawah ini adalah kutipan langsung dari buku Yesus Sang Radikal:

"Anggota badan yang patah tidak boleh dirawat, kuku jari tidak boleh dipotong, kutu pakaian tidak boleh dicari. Apakah orang timpang boleh membawa kaki kayunya keluar rumah dipersoalkan. Menulis lebih dari satu surat dilarang, kecuali kalau ditulis dari bahan sari buah, debu atau pasir dan tidak menghilangkan bekas yang tahan lama. Ember boleh diikat pada ikat pinggang, tetapi tidak boleh pada tali, kalau terjadi kebakaran api tidak boleh dipadamkan, dan hanya boleh menyelamatkan bahan makanan untuk tiga kali makan, dan pakaian sebanyak yang dapat dikenakan (tidak dijinjing); namun boleh menyelamatkan semua salinan kitab suci. ${ }^{16}$

${ }^{13}$ Agnes Maria Layantara, "Filipi: Surat Rasul Paulus Kepada Jemaat Filipi," Yayasan Maranatha Kristen (2007): 13. Jabatan tertinggi bagi orang Yahudi ada 2 yakni ahli Taurat dan orang Farisi.

${ }^{14}$ Kasuistik adalah menurut/berdasar kata hati: kumpulan soal-soal atau kasus yang berkenaan dengan dasar moral;sebab-sebab terjadinya sesuatu; ilmu tentang moral suatu penyakit.

${ }^{15}$ R T France, Yesus Sanga Radikal (Jakarta: BPK. Gunung Mulia, 2002), 90. Misyna disusun sampai akhir abad kedua Masehi, terdiri dari tardisi-tradisi ahli Taurat sejak jauh sebelum zaman Yesus. Di dalamnya ada dua bagian panjang, yang menguraikan secara sangat rinci tentang yang diperbolehkan dan tidak diperbolehkan pada hari Sabat.

${ }^{16}$ Ibid. 
Semua hal terlarang di atas hanya memberikan sedikit gambaran tentang keruwetan argumentasi tentang hari Sabat. Di dalam Misyna, Hagiga mengatakan bahwa peraturan mengenai hari Sabat adalah bagaikan gunung yang bergantung pada sehelai rambut, sebab ayat Kitab Suci tentang itu sedikit, sementara peraturannya jauh lebih banyak. ${ }^{17}$ Dengan demikian, hari yang Allah tentukan sebagai hari peristirahatan, perayaan, penyembahan, sukacita, dan penyegaran baik jasmani maupun rohani, diubah menjadi suatu hari yang penuh dengan pembatasan, tekanan, dan kemurungan.

Ada enam peristiwa di dalam Kitab Injil di mana para pemimpin agama Yahudi bertolak belakang dengan Yesus Kristus dalam hal memaknai hari Sabat. Keenam peristiwa tersebut adalah: murid-murid memetik gandum pada hari Sabat (Mat. 12:1-5); Yesus Kristus menyembuhkan orang yang mati sebelah tangannya pada hari Sabat (Mat. 12:9-14); Yesus Kristus menyembuhkan perempuan yang dirasuki roh selama delapan belas tahun pada hari Sabat (Luk. 13:10-17); Yesus Kristus menyembuhkan seorang yang sakit busung air pada hari Sabat (Luk. 14:1-6); Yesus Kristus menyembuhkan seorang lumpuh di kolam Betsaida pada hari Sabat (Yoh. 5:1-18); dan Yesus Kristus menyembuhkan seorang yang buta sejak lahirnya pada hari Sabat (Yoh. 9:1-41).

Sebagian orang berpandangan bahwa Yesus Kristus dengan sengaja melakukan semua itu pada hari Sabat di hadapan para pemimpin agama Yahudi agar Ia memiliki kesempatan untuk berargumentasi dengan mereka perihal hari Sabat. 18 Pandangan tersebut sulit dipertahankan karena memiliki nuansa subyektivitas yang kental tanpa disertai dukungan data yang obyektif dari Alkitab.

Perlu dicatat bahwa dari semua kisah di atas, tidak ada indikasi Yesus Kristus meniadakan atau menganulir perintah untuk menjalankan hari Sabat. Dalam pengajaran-Nya, Ia menyatakan bahwa Ia tidak pernah meniadakan hukum Taurat dan kitab para nabi, melainkan menggenapinya (Mat. 5:17-18). Artinya, kedatangan-Nya membawa sebuah pengertian dan penerapan yang baru terhadap makna hari Sabat, yang kemudian menjadi penyulut pertentangan antara Ia dan para pemimpin agama Yahudi. Para pemimpin agama Yahudi menuduh-Nya (dan murid-muridNya) melanggar perintah untuk berhenti bekerja pada hari Sabat, karena tindakan murid-murid memetik gandum dan Ia menyembuhkan orang pada hari Sabat dianggap telah melanggar perintah Allah untuk mengadakan perhentian pada hari Sabat.

Dari jawaban-jawaban yang Yesus Kristus berikan dalam setiap peristiwa di atas dapat ditarik sebuah kesimpulan perihal bagaimana Ia memaknai perhentian sebagai manifestasi dari pelaksanaan hari Sabat. Dari

${ }^{17}$ Ibid., 91.

${ }^{18}$ Craig J. Slane, "Sabbath,” in Evangelical Dictionary of Biblical Theology, ed. Walter A. Elwell (Grand Rapids: Baker Academic, 1996), 698. 
keenam peristiwa di atas, secara berturut-turut jawaban yang Yesus Kristus berikan adalah: Ia adalah Tuhan atas hari Sabat (Mat. 12:8) dan hari Sabat diadakan untuk manusia dan bukan manusia untuk hari Sabat (Mrk. 2:27); berbuat baik kepada manusia lebih penting daripada menjalankan hari Sabat (Mat. 12:12); para penentang-Nya adalah orang munafik karena mereka sendiri adalah orang-orang yang melanggar perintah hari Sabat (Luk. 13:15-16); perbuatan baik diizinkan dilakukan pada hari Sabat (Luk. 14:5); dan Ia menyamakan diri-Nya dengan Allah (Yoh. 5:18).

Dari semua respons yang Yesus Kristus berikan di atas, dapat dibuat sebuah kesimpulan yang merangkum pandangan dan pengajaranNya tentang makna dan pelaksanaan perhentian pada hari Sabat, yakni: hari Sabat diadakan untuk manusia, sehingga di hadapan Allah manusia lebih penting daripada hari Sabat, oleh sebab itu makna perhentian hari Sabat boleh diubah demi kebaikan manusia dan Yesus Kristuslah orang yang berhak mengubahnya karena Ia adalah Tuhan atas hari Sabat. ${ }^{19}$

Dengan demikian, Yesus Kristus tidak pernah mengubah esensi hari Sabat sebagai berkat yang Allah berikan bagi manusia. Yang diubah adalah makna dan pelaksanaan perhentian hari Sabat di Perjanjian Lama, yang telah diganti dengan makna baru yang diajarkan oleh-Nya.$^{20}$ Dengan kata lain, perhentian hari Sabat yang ditawarkan oleh-Nya adalah berbeda dengan perhentian yang ditawarkan lewat perintah Allah di Perjanjian Lama. Perhentian yang ditawarkan Yesus Kristus adalah perhentian yang diberikan dalam kapasitas-Nya sebagai Tuhan atas hari Sabat, yakni perhentian yang sudah digenapkan lewat kematian dan kebangkitan-Nya yang membawa kelepasan dan pengampunan dari beban dosa. ${ }^{21}$ Respons terhadap perhentian ini adalah sebuah ibadah yang berisi penyembahan, pujian, ucapan syukur kepada Allah serta persekutuan dengan sesama untuk merayakan perhentian yang sudah digenapkan Allah lewat Yesus Kristus. Selain itu, perhentian eskatologis seperti yang diajarkan di Ibrani 3:7-4:10. Teks ini mengindikasikan adanya perhentian yang belum dimasuki atau diterima oleh orang percaya $(4: 1,9-10)$. Perhentian hari Sabat ini akan didapatkan orang percaya ketika dia berhenti dari segala pekerjaannya, yakni setelah meninggal dunia dan masuk ke sorga, atau ketika kedatangan Yesus Kristus kedua kalinya. Perhentian eskatologis ini disebut juga perhentian "already but not yet," yang artinya di satu pihak orang-orang percaya sudah mendapatkannya lewat iman percaya kepada Yesus

\footnotetext{
${ }^{19}$ Ibid.

${ }^{20} \mathrm{Fu}$, Perhentian Hari Sabat: Makna Dan Aplikasinya Bagi Orang Kristen, 11:237.

${ }^{21}$ Ibid., 11:238.
} 
Kristus, di pihak lain perhentian ini baru akan dinikmati di dalam dunia kekekalan nanti. ${ }^{22}$

\section{Kedudukan Hari Sabat Secara Teologis}

Mengingat dan Menguduskan Hari Sabat

Maksud Allah bagi orang percaya dalam perintah ini yaitu Allah menghendaki orang percaya untuk selalu mengingat hari Sabat bukan sebatas mengingat, merenungkan setelah itu melupakannya, tetapi mengingat yang dimaksudkan Allah adalah mengingat yang berkaitan dengan adanya kepastian dan pengharapan kepada Allah.

Mengingat hari Sabat adalah berkaitan dengan penghargaan serta penghormatan kepada Allah karena karya-Nya yang mulia bagi orang percaya. Dari mengingat memunculkan pengharapan dan keyakinan kepada Allah. Mengingat dalam hal ini berhubungan dengan menyadari pentingnya hari Sabat sebagai hari perhentian yang dikuduskan Allah, dari kesadaran itulah terciptanya pengakuan bahwa ada yang patut dimuliakan yakni Allah itu sendiri.

Selain mengingat Allah pun menghendaki untuk menguduskan hari Sabat. Menguduskan dalam pengertian ini adalah dipisahkan dari hal yang cemar dan mengabdi kepada Allah. Menguduskan memiliki pengertian membersihkan dan memurnikan secara eksternal dan internal. Bagi orang Israel sendiri hari Sabat dijadikan hari tobat hari dimana mereka meyakini mereka telah dibersihkan dan dimurnikan secara eksternal dan internal. Sebagai ucapan syukur hari Sabat dijadikan hari pengabdian kepada Allah. Dalam hal ini berkaitan dengan ibadah kepada Tuhan pada hari Sabat.

Kudus pun memiliki pengertian adanya pembaharuan jiwa, yang berarti bukan hanya menyucikan dari dosa tetapi memulihkan kembali kehidupan jasmani, yaitu memberikan penyegaran dan kelegaan pada tubuh. Jadi menguduskan hari Sabat sangat berperan pada kehidupan rohani dan jasmani bagi yang menerapkannya. Dalam pemeliharaan hari Sabat, ibadah menjadi prioritas dalam segalanya. Ibadah mendapat kedudukan yang penting dalam penyelenggaraan hari Sabat karena dalam ibadah yang sesungguhnya ada pengabdian kepada Allah.

${ }^{22}$ Ibid., 11:239. 


\section{Hari Perhentian/Hari Istirahat}

Hari perhentian atau impilikasinya istirahat yang dimaksudkan Allah bukan berarti tidak melakukan apa-apa (seperti halnya tidur, berdiam diri tanpa tujuan) tetapi beristirahat dalam Tuhan dalam melakukan hal-hal yang berkaitan dengan kehendak Tuhan dan dapat menjadi berkat dalam kehidupan pribadi, dan sesama.

Seperti halnya Kristus membuktikan dari Alkitab sejumlah pekerjaan tertentu dianggap sah di hari Sabat. Pekerjaan itu adalah pekerjaan kesalehan (yaitu yang harus dilakukan agar Allah disembah, seperti pekerjaan Imam dalam mengkhotbahkan Injil di hari Minggu), pekerjaan keharusan (yaitu yang tidak bisa ditunda karena membahayakan jiwa atau harta benda, misalnya menolong seekor kerbau yang terjatuh ke dalam parit, atau membantu memadamkan kebakaran) dan pekerjaan kemurahan hati (seperti tindakan amal terhadap orang yang sakit atau yang kekurangan). Yesus berkata "Yang kukehendaki adalah belas kasihan dan bukan persembahan, tentu kamu tidak menghukum orang yang tidak bersalah. Karena anak Manusia adalah Tuhan atas

\section{Hari Ibadah}

Hari Sabat pun tidak lepas dari hari dimana orang percaya bersekutu bersama dalam peribadahan kepada Tuhan, dengan tujuan menghargai serta menghormati karya Tuhan dalam kehidupan umat-Nya. Memelihara kekudusan hari Sabat berarti orang percaya berkumpul bersama untuk melaksanakan ibadah. Bagi Allah ibadah sangat penting, inilah sebabnya Allah membebaskan umat Israel dari tanah Mesir. Alasan-alasan yang Allah berikan agar umat Allah dapat beribadah (Kel. 7:16; 4:23; 8:1,20; 9:1,13; 10:13). Ini memberikan suatu pengertian bahwa ibadah bersama merupakan kebutuhan bukan sebatas kewajiban.

Ikatan perjanjian dengan Tuhan juga ditandai dengan penetapan ibadah untuk semua umat Tuhan. Ketetapan pertama untuk beribadah bersama adalah perayaan hari Sabat (Kel.20:8-11) dan bentuk kebaktian (Kel. 20:24-26). Pada hakekatnya, ibadah selalu terdiri dari penyerahan diri secara total kepada Tuhan secara pribadi dan bersama yang diatur dengan baik. Ketetapan pertama tentang ibadah bersama adalah perayaan hari Sabat (Kel. 20:8-11) dan bentuk kebaktian (Kel. 20:24-26).

Dalam Perjanjian Lama, korban dilipatgandakan pada hari Sabat. Orangorang datang ke Tabernakel, Bait Allah, ke rumah ibadat untuk menyembah dan di rumah-rumah untuk bersekutu. Umat Allah, baik laki-laki maupun perempuan, 
serta anak-anak semua menyambut Sabat sebagai karunia yang Allah berikan kepada mereka dalam kasih.

Dalam Perjanjian Baru, korban tidak dilipatgandakan. Kristus sebagai satu-satunya korban yang mencukupi dan diperlukan untu pengampunan dosa yang dikorbankan sekali untuk selamnya (Ibrani 7:26-27). Hari perayaannya telah berubah, sifat dari penyembahannya berubah, tetapi keharusan untuk beribadah bersama tidak berubah. Itu sebabnya penulis Surat Ibrani memberikan nasihat yakni:

"Jadi saudara-saudara, oleh darah Yesus kita sekarang penuh keberanian dapat masuk ke dalam tempat kudus, karena Ia telah membuka jalan yang baru dan yang hidup bagi kita melalui tabir, yaitu diri-Nya sendiri, dan kita mempunyai seorang Imam Besar sebagai kepala rumah Allah. Karena itu marilah kita menghadap Allah dengan hati yang tulus ikhlas dan keyakinan iman yang teguh, oleh karena hati kita telah dibersihkan dari hati nurani yang jahat dan tubuh kita telah dibasuh oleh air yang murni. Marilah kita teguh berpegang pada pengakuan tentang pengharapan kita, sebab Ia yang menjanjikannya, setia. Dan marilah kita saling memperhatikan supaya kita saling mendorong dalam kasih dan dalam pekerjaan baik. Janganlah kita menjauhkan diri dari pertemuan-pertemuan ibadah kita, seperti dibiasakan oleh beberapa orang, tetapi marilah kita saling menasihati, dan semakin giat melakukannya menjelang hari Tuhan yang mendekat. (Ibrani 10:19-25)."

Ibadah dalam hari Sabat sangat penting, bahkan Bruce A. Ray berpendapat bahwa sikap tidak berpartisipasi dalam ibadah di gereja apalagi pada hari Sabat bukanlah tanda dari kedewasaan, tetapi tanda dari kemerosotan rohani. ${ }^{23}$ Paul W. Hoon mendefinisikan pentingnya beribadah karena ibadah Kristen merupakan jawaban orang percaya terhadap panggilan Ilahi, terhadap tindakan-tindakan yang penuh kuasa Allah yang berpuncak dalam tindakan pendamaian dalam Kristus. Sedangkan Florovsky menekankan hakikat persekutuan dari tanggapan terhadap panggilan Allah ini yakni: "Keberadaan Kristen adalah secara esensial bersifat persekutuan; menjadi orang Kristen berarti berada dalam komunitas, di dalam gereja. Dalam komunitas inilah Allah aktif dalam ibadah sama seperti orang percaya yang beribadah." ${ }^{24}$ Beribadah dan berbakti kepada Tuhan merupakan tujuan dari istirahat pada hari Sabat. Bukan sekedar istirahatnya semata-mata yang ditekankan, tetapi orang percaya harus beristirahat/berhenti

\footnotetext{
${ }^{23}$ Ray, Merayakan Sabat, 117-118.

${ }^{24}$ James F. White, Pengantar Ibadah Kristen (Jakarta: Bpk. Gunung Mulia, 2012), 9-10.
} 
mengurusi urusan sehari-hari. Supaya bisa menggunakan hari itu untuk berbakti kepada Tuhan. ${ }^{25}$

Selain hari Sabat identik dengan pelaksanaan ibadah, peranan ibadah tersebut pun sangat bermanfaat untuk membangun hubungan yang intim dengan Tuhan serta dapat menciptakan relasi yang baik dan indah antar persekutuan orang percaya. Ibadah dalam hari Sabat bukan hanya kebiasaan orang percaya dahulu, atapun kegiatan yang dilakukan oleh bangsa Yahudi tetapi itu adalah perintah Allah sendiri, dalam Imamat 23:3: "Enam hari lamanya boleh dilakukan pekerjaan, tetapi pada hari yang ketujuh haruslah ada sabat, hari perhentian penuh, yakni hari pertemuan kudus; janganlah kamu melakukan sesuatu pekerjaan; itulah sabat bagi TUHAN di segala tempat kediamanmu".

\section{Peranan Hari Sabat Secara Teologis}

\section{Pengenalan Terhadap Allah}

Dengan menguduskan hari Sabat orang percaya dapat lebih lagi mengenal Allah karena orang percaya berdisiplin untuk memberikan waktu kepada Tuhan. Tiap hubungan memerlukan waktu yang berkualitas, tidak terkecuali hubungan dengan Allah Pencipta dan Penyelamat hidup orang percaya. Menyediakan waktu secara pribadi selama satu hari dalam satu minggu yakni pada hari Sabat merupakan cara yang baik bagi orang percaya untuk membangun hubungan yang indah dengan Allah - hal ini tidak berarti di hari-hari lain hubungan orang percaya dengan Allah menjadi renggang atau terputus, maksud penulis justru di hari perhentian dan istirahat atau hari Sabat dapat menambah keakraban relasi antara Allah dan umat-Nya serta dengan adanya hari Sabat dapat membuat orang percaya berdisiplin dengan waktu-waktu bersama Allah.

Hubungan yang intim terjadi ketika ada waktu yang dilalui secara bersama-sama, diwaktu tersebut membuat adanya pengenalan antara satu dengan yang lain, demikian juga dengan pengenalan kepada Allah. Pengenalan kepada Allah dapat dialami dalam kehidupan orang percaya jika ada waktu untuk menguduskan hari Sabat yang terus diberikan kepada Allah. Pengenalan terhadap Allah adalah hal yang semestinya menjadi tujuan hidup orang percaya, Yoh. 17:3 mencatat hal inilah yang menjadi doa Yesus sebelum Dia disalibkan: "Inilah hidup yang kekal itu, yaitu bahwa mereka mengenal Engkau, satu-

${ }^{25}$ Firman Panjaitan and Marthin Steven Lumingkewas, "Ibadah Jemaat Kristen Kontemporer Abad 21 Dan Tinjauan Kritis-Liturgis," FIDEI: Jurnal Teologi Sistematika dan Praktika 2, no. 1 (2019): 159-182. 
satunya Allah yang benar, dan mengenal Yesus Kristus yang telah Engkau utus."

\section{Providensi Allah}

Seperti halnya orang Israel pada waktu di tanah Mesir mempunyai gaya hidup adalah bekerja tanpa istirahat, namun ketika Allah membebaskan mereka Allah memberikan perintah kepada mereka untuk menguduskan hari Sabat dengan tujuan agar orang Israel dapat percaya pada porovidensi Allah dimana Allah mampu memelihara kehidupan mereka.

Demikian juga dengan orang percaya saat ini. Justru dengan kehidupan yang semakin sulit di dalam dunia ini, orang percaya harus semakin memahami akan providensi Allah dalam kehidupan. Dengan menguduskan hari Sabat dapat membuat orang percaya terlatih untuk meyakini akan providensi Allah. Memberikan 1 hari penuh pada Tuhan atau menguduskan hari Sabat, bukanlah membawa kerugian, justru mengokohkan iman percaya dan meyakini akan campur tangan Allah dalam kehidupan. Ketika Allah tidak memberikan manna pada hari ketujuh, bukan berarti Allah membiarkan umat Israel kelaparan tetapi Allah telah mencukupinya pada hari keenam dengan memberi 2 kali lipat manna sehingga cukup sampai hari ketujuh. Demikan juga dengan orang percaya saat ini, Allah telah mencukupi semua kebutuhan dan Allah mau agar orang percaya menguduskan hari Sabat agar belajar untuk menghargai berkat-berkat yang Allah berikan serta meyakini akan pemeliharaan Allah. Dalam hal ini pun orang percaya dilatih Allah untuk tidak hidup dalam keserakahan.

\section{Peranan Hari Sabat Secara Medis}

Hari Sabat ditetapkan Allah bukan hanya untuk peyegaran akan tubuh rohani tetapi Allah pun menginginkan adanya penyegaran untuk tubuh jasmani. Istirahat bukanlah suatu pemborosan waktu, karena istirahat yang benar ternyata dapat menggandakan efisiensi dan produktivitas. Istirahat membawa pemulihan dan penambahan kekuatan setelah digunakan. Istirahat tidak hanya mencakup tidur, tetapi juga dapat bersantai, perubahan dalam aktifitas, menghilangkan segala tekanan-tekanan atau masalah-masalah.

Studi menjelaskan dimana ketika adanya istirahat, otak dapat berfungsi kembali dengan baik. Daya kerja otak ketika beristirahat sangat penting untuk memori dan fungsi kognitif. Pertumbuhan hormon penting untuk meningkatkan kualitas, ukuran dan efisiensi otak, juga meningkatkan pengangkutan asam amino dari darah ke otak. Kebanyakan dari pertumbuhan hormon diproduksi 
pada saat beristirahat dengan ketenangan. Kurang istirahat, dan lebih buruk lagi, kurang tidur dapat memiliki efek merusak yang menyebabkan penuaan dini, gangguan syaraf, dan gangguan suasana hati. Selama beristirahat tubuh melakukan fungsi-fungsi vital yang penting untuk kesehatan dan umur panjang. ${ }^{26}$ Sebelum dunia medis menemukan manfaat ketika beristirahat, Allah sendiri telah mengetahui hal tersebut, karena Allah lah yang menciptakan manusia, jadi tidaklah heran mengapa Allah ingin agar hari Sabat diterapkan dalam kehidupan orang percaya yakni untuk kebaikan tubuh orang percaya yang adalah Bait-Nya yang kudus.

\section{Peranan Hari Sabat Secara Sosial}

Ketika hari Sabat diterapkan dalam kehidupan orang percaya masa kini maka dapat dipastikan terciptanya relasi yang indah dengan sesama karena perayaan hari Sabat tidak lepas dengan persekutuan orang percaya. Jemaat mula-mula telah membutikan hal tersebut, pada hari pertama Minggu mereka bersama-sama dalam beribadah kepada Tuhan dengan mengingat karya Tuhan yang telah menyelamatkan hidup mereka. Mereka tumbuh dalam kerohanian serta kepedulian terhadap sesama. Orang Israel pun ketika merayakan Sabat mereka merayakan secara bersama-sama, baik itu dengan keluarga maupun dengan saudara-saudara mereka. Ini membuktikan adanya hubungan sosial yang indah dalam kehidupan mereka.

Zaman saat ini menuntut kehidupan yang hanya mementingkan diri sendiri, tanpa disadari ketidakpedulian terhadap sesama pun terabaikan .Dengan adanya persekutuan bersama dapat memberikan hubungan emosional yang baik antar orang percaya pada saat sekarang ini. Terciptanya hubungan sosial yang baik antar orang percaya karena adanya kebersamaan dan kesatuan tubuh Kristus. Di dalam pemahaman Marthin Luther mengenai peranan hari Sabat yakni adanya waktu dan kesempatan untuk bersama-sama, saling berinteraksi, dalam mengikuti kebaktian, berhimpun bersama untuk mendengar dan memperhatikan firman Allah, lalu memuji, bernyanyi dan berdoa, memberikan suatu pengertian dimana hari Sabat pun berperan dalam relasi antar seorang dengan yang lain secara sosial hari Sabat juga berperan penting. Hal ini sangatlah baik dengan

${ }^{26}$ Kevin Adrian, "Cara Meningkatkan Daya Ingat Dan Konsentrasi - Alodokter," accessed March 7, 2020, https://www.alodokter.com/coba-pelajari-cara-meningkatkan-dayaingat-di-sini. 
keadaan saat ini yang seringkali membawa pada kehidupan tanpa interaksi sesama orang percaya bahkan dengan keadaan sekitar. ${ }^{27}$

\section{Peranan Hari Sabat Secara Psikologis}

Orang percaya merayakan hari Sabat dengan penuh sukacita, kesenangan, serta kedamaian dalam hati. Tidak dipenuhi dengan beban dan peraturanperaturan yang harus dipenuhi. Hari Sabat adalah hari kenikmatan yang Allah berikan untuk dinikmati orang percaya. Namun banyak orang percaya yang belum mengerti akan hal ini. Pemahaman yang dimiliki hanyalah sebatas beribadah kepada Allah yang Mahakuasa dengan mengaku dosa, serta mencari anugerah untuk pengudusan diri. Menanggapi sikap orang percaya yang demikian Chantry memberikan pendapatnya bahwa suasana ibadah tidak hanya didominasi oleh beban dan penyesalan, sangat penting memepersembahkan ibadah yang penuh sukacita kepada Allah. Orang percaya harus belajar membangkitkan pujian yang penuh dengan sukacita dalam hati. ${ }^{28}$

Sikap hati yang menjadikan hari Sabat sebagai hari kenikmatan, tidak hanya dapat dilakukan dalam ibadah meskipun prioritasnya dalam ibadah. Namun pada saat merayakan Sabat dengan keluarga atau pun diri sendiri, sikap hati seperti ini sangat diperlukan. Orang percaya patut bersukacita dalam Tuhan karena penebusan dan penyelamatan yang telah Tuhan anugerahkan. Memang sikap hati yang bersukacita tidak hanya dapat dialami dengan usaha diri sendiri, tetapi semua karena Tuhan yang memberikan sukacita tersebut, dan pasti Tuhan memberikannya pada orang percaya yang terus mau mengenal Allah serta percaya pada providensi Allah. Orang-orang seperi inilah yang menjadikan hari Sabat adalah hari kenikmatan.

Orang percaya yang mempunyai sukacita dalam Tuhan dapat dipastikan adalah orang yang selalu menghargai akan perbuatan Tuhan dan orang lain, karena di dalam sukacita itu sendiri ada sikap penghargaan. Noelle C. Nelson, Ph.D dan Jeannine Lemare Calaba, Psy.D. penulis buku The Power of Appreciation berpendapat bahwa penghargaan adalah energi yang bermanfaat bagi jiwa manusia dan berdampak positif karena kekuatan penghargaan dapat mengubah respon tubuh terhadap stress dan untuk mendorong kesehatan yang baik, system kekebalan yang meningkat, energi yang lebih baik, dan

\footnotetext{
${ }^{27}$ Luther, Katekismus Besar, 44.

${ }^{28}$ Ray, Merayakan Sabat, 119.
} 
penyembuhan yang lebih cepat. ${ }^{29}$ Sedangkan mengenai sukacita, ilmu psikologis telah membuktikan bahwa orang yang bersukacita mempunyai semangat hidup yang lebih tinggi, menumbuhkan pikiran-pikiran positif, dapat menanggulangi stress, serta berdampak positif untuk hubungan dengan orang lain. ${ }^{30}$

Ahli psikologi mengatakan bahwa mengucap syukur, bersukacita, ketenangan, merupakan emosi yang paling menyehatkan. Hans Seyle, bapak ilmu stress menyatakan bahwa semuanya itu menimbulkan energi emosi yang lebih dari pada sikap yang lain di dalam kehidupan. ${ }^{31}$ Sebelum penelitian dari berbagai bidang meneliti dan membuktikan hal-hal yang berdampak positif bagi tubuh jasmani, dan jiwa manusia, Allah telah mengetahui terlebih dahulu karena Dia pun adalah pencipta. Jadi ketika Allah menginginkan orang percaya untuk menerapkan adanya hari Sabat itu semua untuk kebaikan. Rancangan Allah adalah rancangan yang membawa kebaikan bagi kehidupan orang percaya dan untuk kemuliaan nama Tuhan.

\section{Simpulan}

Dari penelusuran atas makna dan peranan hari Sabat berdasarkan teologi biblika maka dimpulkan bahwa: pertama, hari Sabat merupakan perintah Allah kepada kepada umat-Nya untuk berhenti dari segala pekerjaan oleh semua anggota keluarga, termasuk orang asing, budak dan binatang peliharaan. Kedua, hari Sabat menyentuh dimensi vertikal dan horizontal. Dimensi vertikal agar umat Israel mengenang Allah untuk mengadakan persekutuan yang penuh sukacita dengan-Nya dan mengakui Allah sebagai Pencipta yang mengatur, memelihara, dan memiliki segala sesuatu, termasuk umat Israel. Sedangkan berhubungan dengan dimensi horisontal yang mengingatkan bangsa Israel bagaimana Allah telah melepaskan mereka dari penderitaan sebagai budak di masa lampau, sehingga mereka juga memberikan perhentian kepada seisi keluarganya. Ketiga, Yesus Kristus adalah Tuhan atas hari Sabat. Ia memiliki otoritas untuk mengubah makna dari hari Sabat. Makna perhentian hari Sabat yang diberikan-Nya adalah perhentian sebagai hasil dari kelepasan dari beban

${ }^{29}$ Noelle C. Nelson and Jeannine Lemare Calaba, The Power of Appreciation, (Jakarta: PT. Bhuana Ilmu Populer, 2005), 4-5.

${ }^{30}$ Allert Benedicto Ieuan Noya, "Bebas Dari Penyakit Berkat Berpikir Positif," Alodokter.Com, last modified 2019, accessed February 5, 2020, https://www.alodokter.com/bebas-dari-penyakit-berkat-berpikir-positif.

${ }^{31}$ Rick Warren, "Cara Untuk Mengembangkan Sucacita," accessed March 3, 2020, https//: cahayapengharapan.org/ cara-untuk-mengembangkan-sukacita/. 
dosa dan perhentian eskatologis yang akan diterima semua orang percaya dalam dunia kekal di sorga. Keempat, hari Sabat diadakan untuk manusia dan bukan manusia untuk hari Sabat. Sehingga di hadapan Allah manusia lebih penting daripada hari Sabat, oleh sebab itu makna perhentian hari Sabat boleh diubah demi kebaikan manusia dan Yesus Kristuslah orang yang berhak mengubahnya karena Ia adalah Tuhan atas hari Sabat. Kelima, penerapan hari Sabat berawal dari konsep yang benar mengenai hari Sabat itu sendiri. Yakni bukan berpatokan pada hari tertentu dan peraturanperaturan yang membebankan namun pada inti Sabat itu sendiri yakni hari kenikmatan yang ditetapkan Tuhan untuk dipelihara sesuai dengan kehendak Tuhan. Keenam, peranan hari Sabat dalam kehidupan orang percaya mencakup secara keseluruhan yakni secara rohani dan jasmani. Secara rohani peranannya yakni adanya pengenalan terhadap Allah, meyakini akan providensi Allah, serta menyangkal diri untuk melakukan apa yang Tuhan kehendaki. Sedangkan dalam hidup jasmani yakni memberikan kesehatan pada jiwa yang sakit, sukacita pada pada hati dan pikiran, merawat organ-organ tubuh agar dapat bekerja maksimal serta membangun hubungan atau relasi yang baik dengan sesama. Hari Sabat tidak sekedar mengatur hubungan ritual dan vertikal antara manusia dengan Allah. Namun lebih dari itu juga hari Sabat menata hubungan horizontal antar sesama manusia, bahkan dengan mahluk hidup lainnya.

\section{Daftar Pustaka}

Adrian, Kevin. "Cara Meningkatkan Daya Ingat Dan Konsentrasi - Alodokter." Accessed March 7, 2020. https://www.alodokter.com/coba-pelajari-carameningkatkan-daya-ingat-di-sini.

Archer, Gleason L. Encyclopedia of Bible Difficulties. Malang: Gandum Mas, 1982.

Darmaputera, Eka. Sepuluh Perintah Tuhan, Museumkan Saja? Yogyakarta: Gloria Graffa, 2005.

France, R T. Yesus Sanga Radikal. Jakarta: BPK. Gunung Mulia, 2002.

$\mathrm{Fu}$, Timotius. Perhentian Hari Sabat: Makna Dan Aplikasinya Bagi Orang Kristen. Veritas: Jurnal Teologi Dan Pelayanan. Vol. 11. Malang: Seminari Alkitab Asia Tenggara Malang, 2010.

Hadley, Judith M., and J. J. Owens. "Analytical Key to the Old Testament 4: Isaiah-Malachi." In Vetus Testamentum, 41:512. Joshua: Grand Rapids, 1991.

Hinson, David F. Sejarah Israel Pada Zaman Alkitab. Jakarta: Bpk. Gunung 
Mulia, 2001.

Karman, Yongky. Bunga Rampai Teologi Perjanjian Lama. Jakarta: BPK. Gunung Mulia, 2005.

Layantara, Agnes Maria. "Filipi: Surat Rasul Paulus Kepada Jemaat Filipi." Yayasan Maranatha Kristen (2007).

Luther, Martin. Katekismus Besar. Jakarta: BPK. Gunung Mulia, 2007.

Nelson, Noelle C., and Jeannine Lemare Calaba. The Power of Appreciation,. Jakarta: PT. Bhuana Ilmu Populer, 2005.

Noya, Allert Benedicto Ieuan. "Bebas Dari Penyakit Berkat Berpikir Positif." Alodokter.Com. Last modified 2019. Accessed February 5, 2020. https://www.alodokter.com/bebas-dari-penyakit-berkat-berpikir-positif.

Panjaitan, Firman, and Marthin Steven Lumingkewas. "Ibadah Jemaat Kristen Kontemporer Abad 21 Dan Tinjauan Kritis-Liturgis." FIDEI: Jurnal Teologi Sistematika dan Praktika 2, no. 1 (2019): 159-182.

Putera, Eka Darma. "Hak Beristirahat Untuk Yang Bekerja." Accessed March 12, 2020. https://archive.org/stream/ ekadarmaputera/.

Ray, Bruce A. Merayakan Sabat. Surabaya: Momentum, 2006.

Silalahi, Anton. Hari Perhentian, Mengapa Hari Sabtu? Jakarta: Talenta Mulia Aksara, 2008.

Slane, Craig J. "Sabbath." In Evangelical Dictionary of Biblical Theology, edited by Walter A. Elwell. Grand Rapids: Baker Academic, 1996.

Warren, Rick. "Cara Untuk Mengembangkan Sucacita." Accessed March 3, 2020. https//: cahayapengharapan.org/ cara-untuk-mengembangkansukacita/.

White, James F. Pengantar Ibadah Kristen. Jakarta: Bpk. Gunung Mulia, 2012.

Williamson, G I. Pengakuan Iman Westminster. Surabaya: Momentum, 2006. 